Article

\title{
Surface Salinization of Soil under Mulched Drip Irrigation
}

\author{
Hongguang Liu ${ }^{1}$, Mingsi Li ${ }^{1, *}$, Xurong Zheng ${ }^{1}$, Yaqin Wang ${ }^{2}$ and Sumera Anwar ${ }^{3, *}$ \\ 1 College of Water Conservancy and Architectural Engineering, Shihezi University, Shihezi 832000, China; \\ liuhongguang-521@163.com (H.L.); zhengxurong@126.com (X.Z.) \\ 2 Corps Division 8, Soil Improvement Experimental Station, Xinjiang Production and Construction, \\ Paotai Town, Shihezi 832000, China; wyaqin99@outlook.com \\ 3 The Institute of Molecular Biology and Biochemistry, The University of Lahore, Lahore 54000, Pakistan \\ * Correspondence: limingsi@shihzu.edu.cn (M.L.); sumeraanwar@imbb.uol.edu.pk (S.A.)
}

Received: 11 August 2020; Accepted: 26 October 2020; Published: 28 October 2020

check for updates

\begin{abstract}
The mulched drip-irrigation technique has been widely employed in Xinjiang, China, however, it was found to result in the buildup of salt in the surface soil. To ascertain the effect of mulched drip irrigation on salinization, experiments were carried out during 2009-2010 in two fields of mulched soil drip irrigated for three and 13 years. The solute transportation in soil was simulated with the MATLAB system based on the Richards equations. Results showed that the soil mulched by plastic film did not accumulate salt, but the bare soil surface accumulated salt and the salinity distribution in bare soil was in the ' $\Gamma^{\prime}$ pattern. The soil layer below a depth of $20 \mathrm{~cm}$ in the bare area showed desalination because its salt content was $22 \%$ less than the surface. The salinity of bare surface soil including cultivated horizon was reduced by $17 \%$ after 13 years of drip irrigation. The simulation results indicated that the solutes of mulched soil were transported vertically to deep soil and transversely to the bare soil with drip irrigation. Thus, the salt accumulated on the surface of bare soil came from the soil mulched by plastic film, not from groundwater or saline irrigation water and did not cause secondary salinization.
\end{abstract}

Keywords: mulched drip-irrigation; soil solute; surface salinization; water-solute movement in soil; secondary salinization

\section{Introduction}

Since the successful trial of mulched drip-irrigation technology by Xinjiang Production and Construction Corps in 1996, it has been widely applied in arid and semi-arid regions in China and has even been promoted in some countries of Central Asia. However, mulched drip-irrigation is characterized by shallow irrigation and has no leaching [1,2], and it has been reported to move salt under the mulched soil to the bare land outside the mulch [3]. Mmolawa and Or [4] showed that in a humid area, salt under drip irrigation accumulated at the edges of the wetting front and lowered the soil salinity under the cultivated area, which aided crop root growth [4]. Therefore, some scholars have thought that the accumulation of salt in the bare land outside the mulching with the drip irrigation and salt accumulation at the edges of the wetting front without elution would lead to soil secondary salinization [5-8].

Secondary soil salinization is different from the salinization of surface soil. Secondary salinization generally refers to salt retention in the plow layer or on the soil surface from rising underground water and moisture evaporation [9] or irrigation with brackish water. Whereas, in the salinization of surface soil, there is a sudden change in salt content in the surface soil. In the Xinjiang region, salt content in 
the $0-10$-or $0-20$-cm layer is more than five times the average salt content in deeper soil, and generally, the surface salt content is $>100 \mathrm{~g} \mathrm{~kg}^{-1}$ [10].

It has been predicted that mild salinization under mulch drip irrigation might advance into severe secondary salinization after 40-70 years. However, Wang et al. [11] found that the salt below the emitter tended to move downward, forming a salt-diluted area, while in the bare area outside the mulch, salt moved upward, forming an area of salt accumulation. The halomorphic soil in the area outside the mulch indicated the directional salt exclusion under drip irrigation [12]. Thus, desalination occurred in soil under the mulch, and salt deposition occurred in the soil outside the mulch during the irrigation period.

In secondary soil salinization, the salt accumulation in a layer (usually the plow layer) is driven by salt flux from underground water toward the surface, which reduced the underground salt content [13-15]. Zhang [16] showed that high-frequency drip irrigation effectively reduced the salt content of the wetting body. Tan [17] observed that the salt was leached to various degrees and was reduced by $25 \%-44 \%$ and the reduction was especially significant in the first years of reclamation for the drip irrigation of maize. Kang et al. [18] studied the effect of drip irrigation on soil salinization by maintaining soil water potential and showed that soil could be desalted up to $64 \%$ at a depth of $0-120 \mathrm{~cm}$ by the drip irrigation [19].

Efforts should be made to understand the mechanisms and effects of soil salinization caused by mulched drip-irrigation in Xinjiang as well as other similar agroecosystems around the world. Therefore, in this study, we explored the relationship of drip-irrigation under mulching with the accumulation and distribution of salt in the soil based on field observations and numerical simulations to ascertain the effect of mulched drip irrigation on salinization.

\section{Materials and Methods}

\subsection{Description of Experimental Field}

From April 2009 to October 2010, a trial was conducted at two adjoining fields ( $44^{\circ} 48^{\prime} \mathrm{N}, 85^{\circ} 34^{\prime} \mathrm{E}$ and height between 332 to $333 \mathrm{~m}$ ) in Paotai Town, the 8th division of Xinjiang Production and Construction Corps, China (Figure 1). The average annual rainfall in this location is $180 \mathrm{~mm}$ and the average annual evapotranspiration is $2400 \mathrm{~mm}$. Average evaporation peak during the beginning of June to mid-July, which wis $7-8 \mathrm{~mm} \mathrm{~d}^{-1}$.

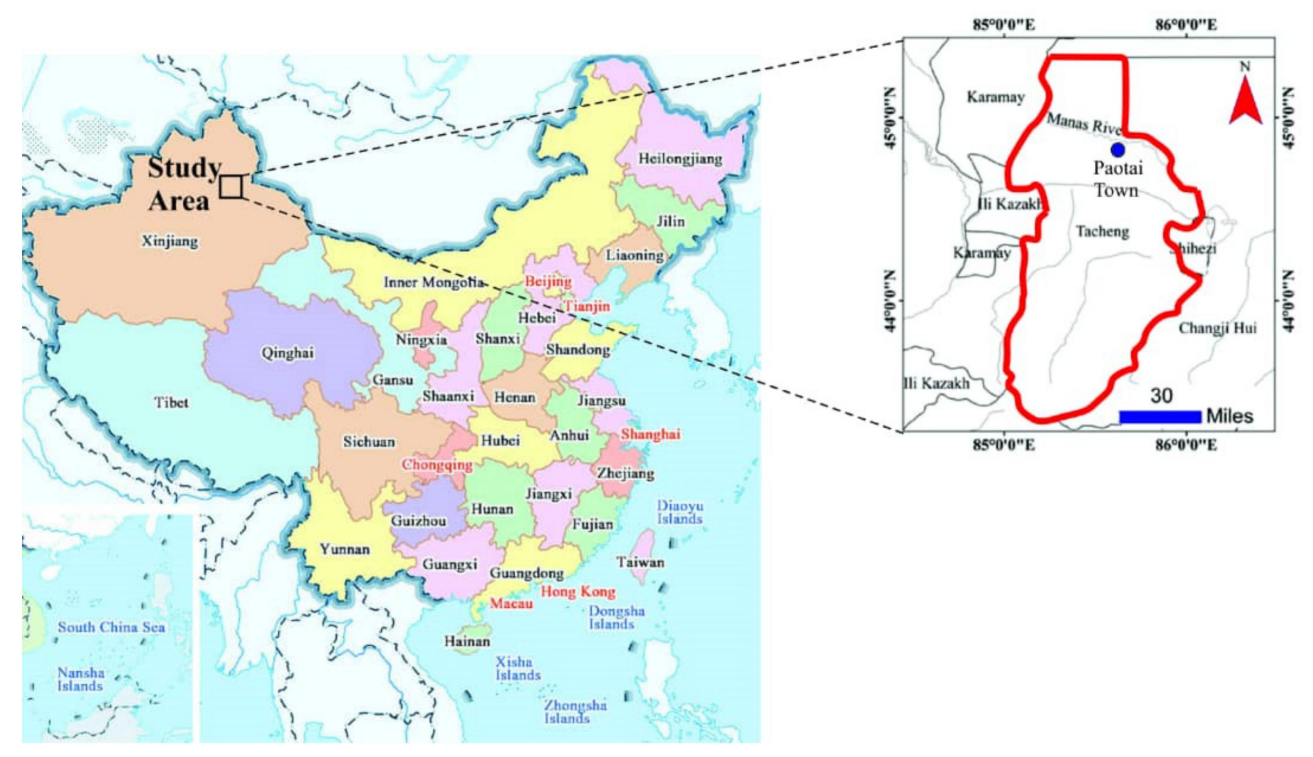

Figure 1. The geographical location of Xinjiang in China and the experimental station at Paotai Town in Xinjiang. 
The area of field 2 was 10 ha, reclaimed in 2008, and the average salt content in the $0-30-\mathrm{cm}$ soil layer was $26.9 \mathrm{~g} \mathrm{~kg}^{-1}$. Field 1 with an area of 15 ha was reclaimed in 1997, and the average salt content in the $0-30-\mathrm{cm}$ layer was $29.5 \mathrm{~g} \mathrm{~kg}^{-1}$. After reclaiming these fields, mulched drip irrigation was applied for cotton cultivation [20].

Soil analysis in 2009 showed that the soil texture of field 2 was heavy loam with $46 \%$ clay content, $1.49 \mathrm{~g} \mathrm{~cm}^{-3}$ bulk density, and $22.6 \%$ field capacity. The soil texture of field 1 was middle loam soil with $20.5-24 \%$ clay content, $1.49 \mathrm{~g} \mathrm{~cm}^{-3}$ bulk density, and field capacity was $21.7 \%$. There was a monitoring well in the southeast corner of field 2 at the upstream of the field. In 2009, the depth of the water table during the growth period of cotton was $3.4 \mathrm{~m}$ in 2009, while during 2010, the depth of the water table was $3.4 \mathrm{~m}$ in April and was increased in June and July to $3.6 \mathrm{~m}$ and $3.57 \mathrm{~m}$ in September (Table 1).

Table 1. Depth to water table (m) in field 2.

\begin{tabular}{ccccccc}
\hline Year & April & May & June & July & August & September \\
\hline 2009 & 3.40 & 3.40 & 3.40 & 3.40 & 3.40 & 3.40 \\
2010 & 3.40 & 3.40 & 3.64 & 3.60 & 3.43 & 3.57 \\
\hline
\end{tabular}

The cotton (Gossypium hirsutum) variety used for planting during 2009-2010 was '710' (which belongs to a series of 'Xinluzao'). Cotton was seeded on 21 April into dry soil. The mulch width was $120 \mathrm{~cm}$ and the bare area outside the mulch was $20 \mathrm{~cm}$ wide (Figure 2). Below mulch, there were four rows of plants with wide and narrow row spacings of $15 \mathrm{~cm}+66 \mathrm{~cm}+15 \mathrm{~cm}$, the best-suited model for mechanical harvesting. In a row, plant to plant spacing was $10 \mathrm{~cm}$, and the drip irrigation belt was at the center below the mulch.

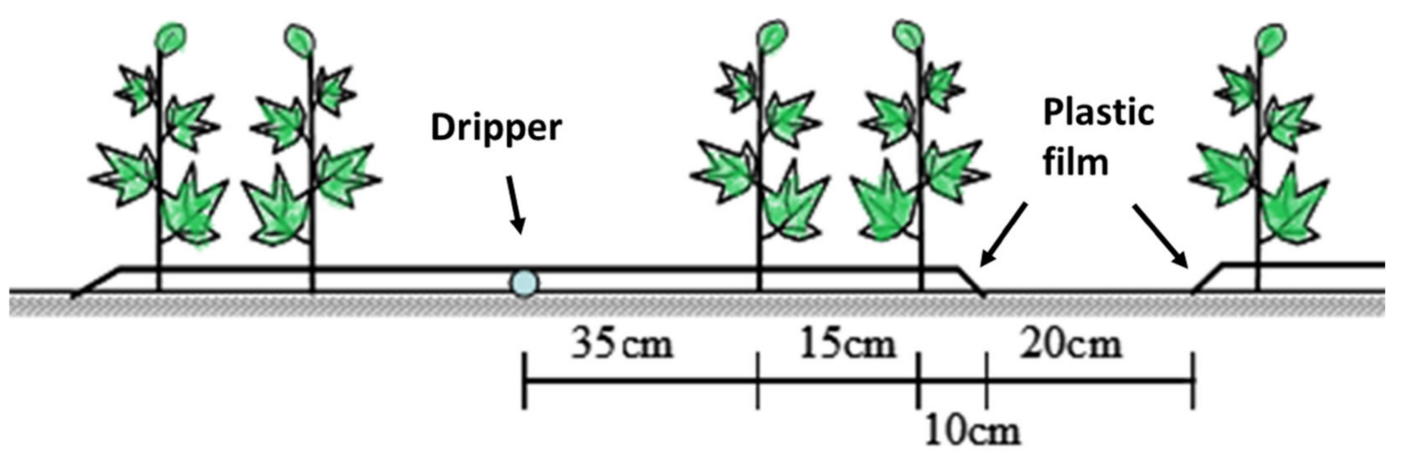

Figure 2. Layout of mulched drip irrigation technique in the cotton field.

The salts in the irrigation water were less than $1.3-1.8 \mathrm{~g} \mathrm{~L}^{-1}$, and thus suitable for irrigation. The row space of emitters was $30 \mathrm{~cm}$, the designed emitter flow was $2.8 \mathrm{~L} \mathrm{ha}^{-1}$, and the pressure for each emitter was $0.1 \mathrm{MPa}$. The moist areas under emitters were intersected, completely forming a uniform wetted area under mulch. In field 2, the cotton was irrigated every 10 to 15 days using the irrigation amount of 450-525 $\mathrm{m}^{3} \mathrm{ha}^{-1}$ (Table 2). Field 1 was irrigated twice from 16 July to 20 July 2009 and the total irrigation rate was $900 \mathrm{~m}^{3} \mathrm{~h}^{-1}$.

Table 2. Cotton irrigation schedule in the test plot.

\begin{tabular}{ccccccccccc}
\hline Date & 2 May & 17 May & 30 May & 10 June & 20 June & 1 July & 12 July & 22 July & 4 August & 25 August \\
\hline $\begin{array}{c}\text { Irrigation amount } \\
\left(\mathrm{m}^{3} \mathrm{ha}^{-1}\right)\end{array}$ & 525 & 450 & 450 & 450 & 525 & 525 & 525 & 525 & 525 & 450 \\
\hline
\end{tabular}

\subsection{Soil Sampling}

The soil samples were collected from the middle of the bare area outside mulching and from the middle of the under mulched area directly under the irrigation zone from every $10 \mathrm{~cm}$ to a total depth 
of $140 \mathrm{~cm}$. The salt contents were measured and the distribution of soil was compared for the two sites. For field 2, we simultaneously measured the salt content of the sample soil from uncultivated and reclaimed land to observe the changes in salt content in reclaimed soil after drip irrigation. An FG3-ELK conductivity apparatus was used to measure the conductivity of soil leaching liquor and the drying residue method was used to demarcate it.

\subsection{Migration Simulation of Soil Salt of Bare Area in Condition of Outside-Mulch Evaporation}

To ascertain the relationship between salt content under mulch and bare area, and to trace the origin of salt content in the bare area, we simulated the migration of soil salt using MATLAB on the basis of the Richards equation [21].

\subsubsection{Basic Equation}

It was considered that the soil salt transferred with the movement of soil water.

$$
\frac{\partial(\theta \times c)}{\partial t}=\frac{\partial}{\partial x}\left[D(\theta) \frac{\partial(\theta \times c)}{\partial x}\right]+\frac{\partial}{\partial z}\left[D(\theta) \frac{\partial(\theta \times c)}{\partial z}\right]+\frac{\partial k(\theta \times c)}{\partial z}
$$

where $\theta$ is the soil volumetric moisture content; $\mathrm{c}$ is solution concentration; $\mathrm{t}$ is time; $D(\theta)$ is diffusion rate of soil water; and $k(\theta)$ is the transmissivity of soil (or soil hydraulic conductivity).

In this equation, the hydrodynamic dispersion could be ignored, the soil was homogeneous and isotropic, and decoupling existed between the motion equation and the solute transport Equation (1) could be simplified as Equation (2):

$$
\frac{\partial \theta}{\partial t}=\frac{\partial}{\partial x}\left[D(\theta) \frac{\partial \theta}{\partial x}\right]+\frac{\partial}{\partial z}\left[D(\theta) \frac{\partial \theta}{\partial z}\right]+\frac{\partial k(\theta)}{\partial z}
$$

\subsubsection{Boundary Conditions}

The area, which comprised the mulch covered area and the two sides of bare land outside, was the computational domain, the computational depth was $140 \mathrm{~cm}$, and the computational width, which contained the two sides of bare land, was $160 \mathrm{~cm}$. The surface under-mulch was the irrigation area. Supposing it could be equally irrigated and the emitter rate of flow was $2.8 \mathrm{~L} \mathrm{~h}^{-1}$, we calculated the infiltration intensity of the under-membrane surface as $56 \mathrm{~mm} \mathrm{~d}^{-1}$. The bare area was the evaporation area, according to the computed ET0 $(5-7 \mathrm{~mm})$ and the assumption that evaporation in the bare area was almost steady, the evaporation intensity at the surface of the bare area should be $5 \mathrm{~mm} \mathrm{~d}^{-1}$. The entire soil surface was assumed to fit the Neumann condition.

The flanks and the bottom of the calculation zone were free-infiltrated and the Neumann condition was applied:

$$
\vec{n} \times(D(\theta) \times \nabla \theta)+q \times \theta=g
$$

If we assumed $g=0$ and the initial moisture content distribution was homogeneous, then the water content was $16 \%$ and the mass fraction of salt was $27 \mathrm{~g} \mathrm{~kg}^{-1}$.

\subsubsection{Soil Moisture Characteristics}

The soil moisture characteristic curve of field 2 was measured by the pressure film instrument, and all the fitting parameters for the van Genuchten model (Equation (4)) were as follows [22]:

$$
\theta=\theta_{r}+\frac{\theta_{s}-\theta_{r}}{\left[1+(\alpha h)^{n}\right]^{m}}
$$


The fitting model for the van Genuchten model were as follows: $\theta_{r}=0.129 \mathrm{~cm}^{3} \mathrm{~cm}^{-3}$; $\theta_{s}=0.45 \mathrm{~cm}^{3} \mathrm{~cm}^{-3} ; \alpha=0.075 ; n=1.89 ; 1=0.5$. The infiltration rate of soil was measured by a vertical infiltration apparatus and the saturated hydraulic conductivity was calculated as $K_{s}=76 \mathrm{~cm} \mathrm{~d}^{-1}$.

\subsubsection{Hydrodynamic Parameters of Soil}

From the soil moisture characteristic curve and saturated hydraulic conductivity of field 2, we obtained the water diffusivity $D(\theta)$, which is defined as Equation (5) [22]:

$$
D(\theta)=D_{0}\left(\frac{\theta}{\theta_{s}}\right)^{m}
$$

\subsection{Numerical Model Calibration and Verification}

The root mean square error (RMSE) method can quantitatively analyze the accuracy of the measured and the simulated value and was used to verify the reliability of the simulation results. The RMSE was calculated as follows:

$$
\mathrm{RMSE}=\sqrt{\frac{1}{n} \sum_{i=1}^{n}\left(x_{i}-y_{i}\right)^{2}}
$$

where $x_{i}$ is the measured value; $y_{i}$ is the analog value; and $n$ is the number of samples.

\section{Results}

\subsection{Changes in Salt Distribution by Drip Irrigation in Naturally Saline Soil}

The salt content in field 2 was measured to observe the effect of drip irrigation under mulching on the vertical distribution of salt in naturally saline soil under mulching and bare soil (Figure 3). The salt content distribution of the uncultivated area remained unchanged from 2009 to 2010 (Figure 3a) and considered in the natural steady state. Although salt content on the surface was $30-40 \mathrm{~g} \mathrm{~kg}^{-1}$, it was not changed with irrigation. With an increase in the soil depth, the mass fraction of salt decreased by $0.21 \mathrm{~g} \mathrm{~kg}^{-1} \mathrm{~cm}^{-1}$, which almost showed the decreasing trend. At a depth of $140 \mathrm{~cm}$, the mass fraction of salt was in the range of $4-6 \mathrm{~g} \mathrm{~kg}^{-1}$.

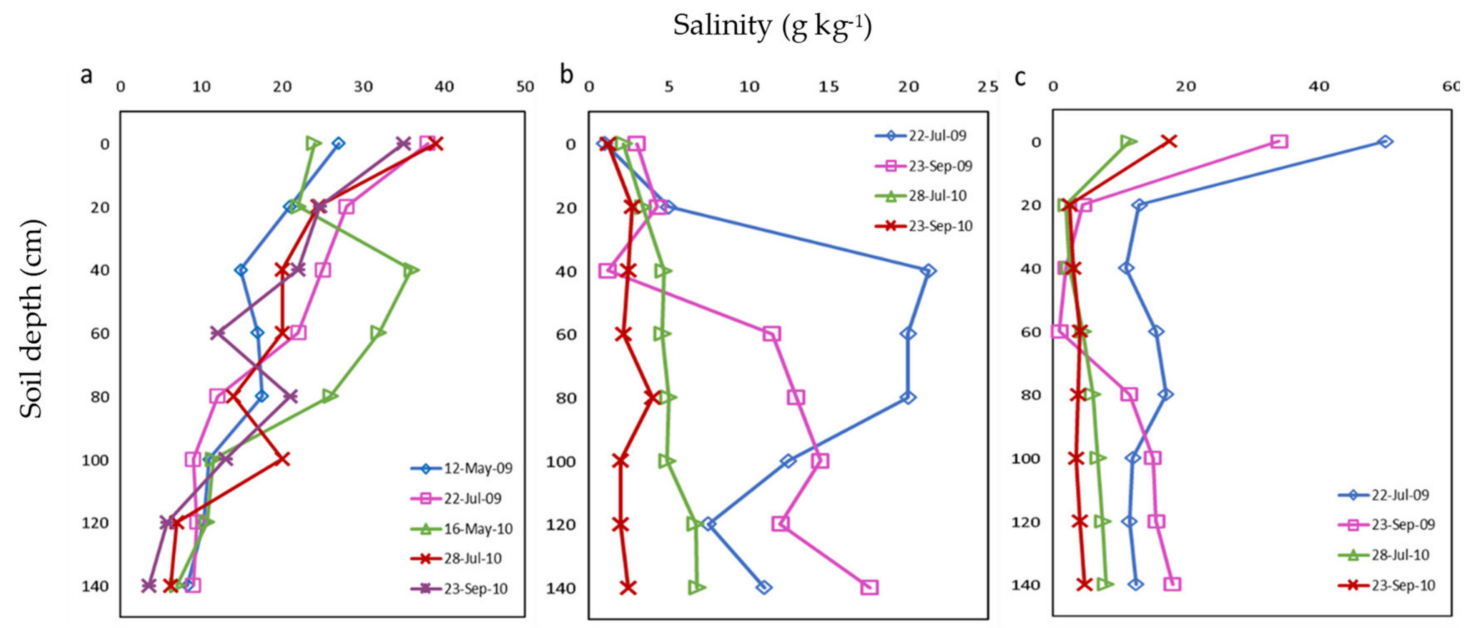

Figure 3. Distribution of soil salinity during 2009-2010 in field 2: (a) uncultivated land; (b) under mulch; and (c) in the bare area outside the mulch.

The mass fraction of salt in soil under the mulching area declined with drip irrigation (Figure 3b). The salt content of the 0-20-cm layer reduced gradually with the extended use of drip irrigation, while 
the salt content in the $20-80 \mathrm{~cm}$ first increased from the original natural state (Figure 3a), and then gradually reduced, and at the end, the salt concentration was less than $5 \mathrm{~g} \mathrm{~kg}^{-1}$. Compared with the upper layers, the salt content change in 80-140 cm showed a delayed response and finally reached a concentration of less than $5 \mathrm{~g} \mathrm{~kg}^{-1}$. These results implied that the salt content under mulching was reduced mainly due to the leaching by drip irrigation from the upper to the deeper layer.

There was a sudden change in soil salt content in the bare area outside the mulch at a $20 \mathrm{~cm}$ depth (Figure 3c). On 22 July 2009, the mass fraction of salt in the surface soil in the bare area outside the mulch was $135 \mathrm{~g} \mathrm{~kg}^{-1}$; while at the depth of $20 \mathrm{~cm}$ was $11.25 \mathrm{~g} \mathrm{~kg}^{-1}$, which was $8.3 \%$ of that on the surface. The mass fraction of salt below the depth of $20 \mathrm{~cm}$ was less than $20 \mathrm{~g} \mathrm{~kg}^{-1}$, which was $15 \%$ of that at the surface. The continuous application of drip irrigation reduced the salt content on the surface. On 23 September 2010, the mass fraction of salt on the surface was $17.7 \mathrm{~g} \mathrm{~kg}^{-1}$, while below the depth of $20 \mathrm{~cm}$ it was $<4 \mathrm{~g} \mathrm{~kg}^{-1}$, which was $22.5 \%$ less than at the surface. The result showed that the high salt content on the surface of the bare area outside the mulch was due to the accumulation of salt by salt transportation from the mulched irrigated area, whereas the salt content in the deep layers was reduced with the application of drip irrigation.

\subsection{Long-Term Changes in Soil Salt Distribution by Drip Irrigation under Mulching}

To determine whether salt content would increase with the extended use of drip irrigation, we observed salt content distribution in 2010 for field 1, which was under drip irrigation and mulching for 13 years. The salt content in the bare area outside the mulch was sharply reduced after drip irrigation (Table 3).

Table 3. Soil salinity distribution in field $1\left(\mathrm{~g} \mathrm{~kg}^{-1}\right)$.

\begin{tabular}{|c|c|c|c|c|c|}
\hline Sampling Area & Soil Layer Depth (cm) & \multicolumn{4}{|c|}{ Sampling Date } \\
\hline \multirow{4}{*}{ Mulching } & 0 & 2.28 & 0.88 & 0.52 & 0.55 \\
\hline & 20 & 2.24 & 0.84 & 0.53 & 0.74 \\
\hline & 30 & 2.53 & 1.18 & 0.55 & 0.55 \\
\hline & 40 & 2.52 & 1.17 & 0.62 & 0.61 \\
\hline \multirow{4}{*}{ Bare soil } & 10 & 3.32 & 2.11 & 0.87 & 0.97 \\
\hline & 20 & 2.50 & 1.14 & 0.98 & 0.84 \\
\hline & 30 & 2.72 & 1.41 & 0.97 & 0.47 \\
\hline & 40 & 2.63 & 1.30 & 1.07 & 0.60 \\
\hline
\end{tabular}

In mid-May, the mass fraction of salt in the plow layer $(0-40 \mathrm{~cm})$ under mulch was less than $3 \mathrm{~g} \mathrm{~kg}^{-1}$, which was reduced with time, and in late July, it was less than $1 \mathrm{~g} \mathrm{~kg}^{-1}$. The vertical distribution of salt content remained the same from the surface to a depth of $40 \mathrm{~cm}$. At the same time, salt content in the bare area outside the mulch was more in the surface layer and was decreased with depth. The mass fraction of salt in the surface of the bare area generally remained in the range of 2-5 $\mathrm{g} \mathrm{kg}^{-1}$, showing that the salt distribution in the bare area was still characterized by salt accumulation at the surface. The salt content in the bare area outside the mulch was much lower than the original natural salt $\left(29.5 \mathrm{~g} \mathrm{~kg}^{-1}\right)$ for field 1 . Thus, 13 years of drip irrigation reduced the salt content of field 1 , although for the bare area, there was more salt on the surface than in the subsurface layer.

\subsection{Coupling Simulation of Soil Salt and Water}

The motion simulation of soil salt and water in irrigation is shown in Figure 4. With drip irrigation, both the under mulch and the bare area outside the mulch showed that water infiltration and under mulching were more deeply infiltrated. The soil moisture content and water infiltration was more for the area under mulching than the bare area outside mulching. The salt content in the under-mulched area moved downward with water, and thus the salt content under the mulch surface was low. At the 
same time, the salt moved horizontally from under mulching to the bare area and accumulated on the surface due to surface evaporation, and thus salt content increased in the bare area. However, the salt in the bare area mostly accumulated to a depth of $20 \mathrm{~cm}$ and then decreased gradually with the depth. The simulation result showed that the increased salt content in the bare area outside the mulch mainly came from the horizontal movement of soil salt and not from rising underground water; therefore, the salt on the surface was due to the redistribution of salt, and not secondary salinization.

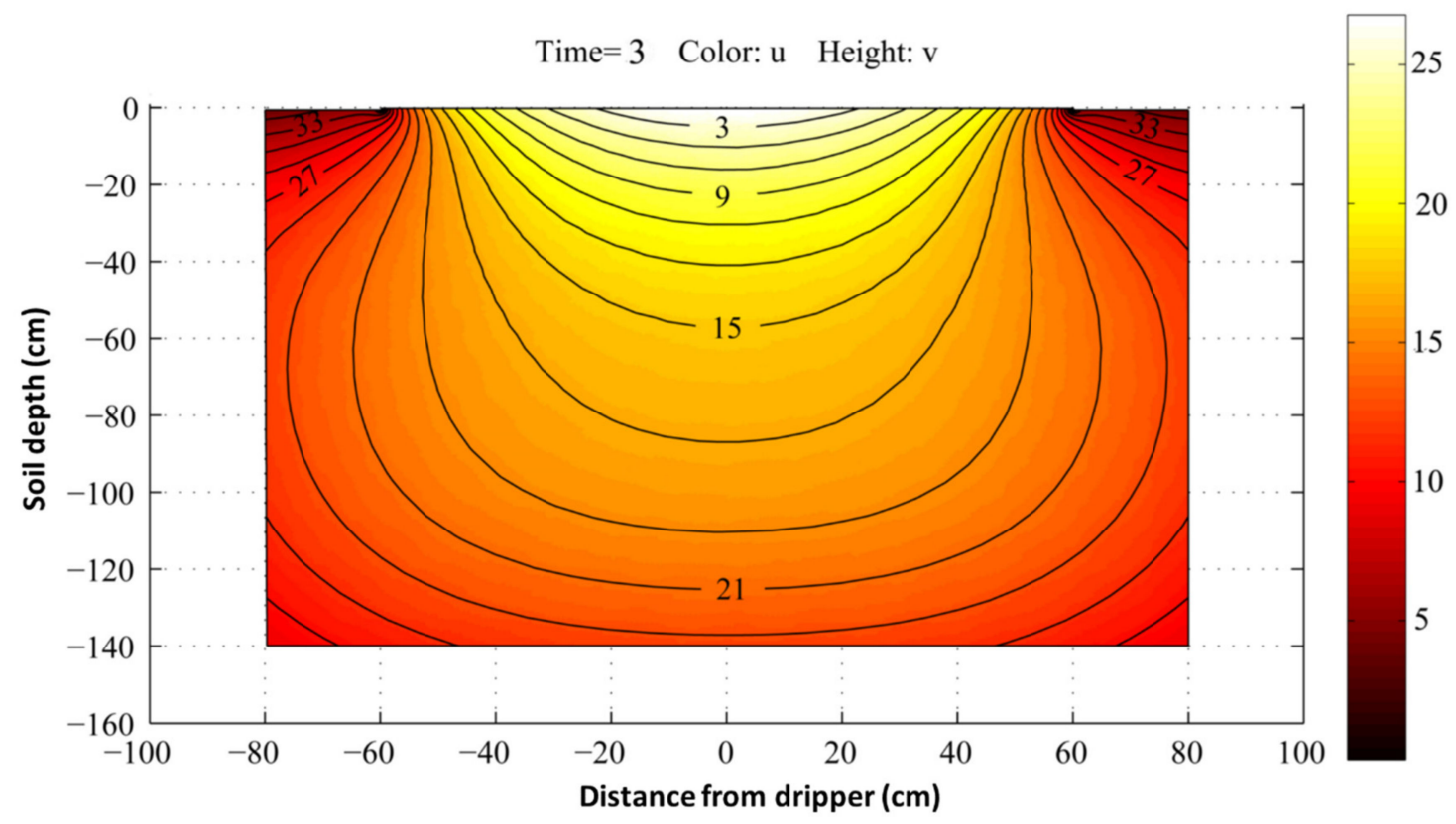

Figure 4. The coupled transport of salt and water in the field under mulched drip irrigation (Color: soil gravimetric moisture content (\%); Contour line: soil salinity $\left(\mathrm{g} \mathrm{kg}^{-1}\right)$; Ordinate: soil depth $(\mathrm{cm})$; Abscissa: horizontal distance from drip line $(\mathrm{cm})$ ).

Root mean square error (RMSE) and coefficient of determination $\left(\mathrm{R}^{2}\right)$ were used to access the level of agreement between the simulated and observed values. It can be seen from Tables 4 and 5 that the RMSE values of the simulated and measured values for the bare and mulched soil were 0.47 and 0.50 , respectively, and $\mathrm{R}^{2}$ between the measured and simulated values were higher than 0.9 . This indicates that the model can relatively predict the data accurately and measured values were not much different from the simulated values, and the parameters were relatively small and reliable.

Table 4. Root mean square error (RMSE) value of measured value and simulated value.

\begin{tabular}{cc}
\hline Bare Soil & Mulching \\
\hline 0.4743 & 0.5051 \\
\hline
\end{tabular}

Table 5. Correlation $\left(\mathrm{R}^{2}\right)$ between the measured and simulated values.

\begin{tabular}{cc}
\hline Bare Soil & Mulching \\
\hline 0.9507 & 0.9579 \\
\hline
\end{tabular}

\section{Discussion}

It is still debatable whether secondary salinization would arise from mulched drip-irrigation. Some researchers believe that mulched drip-irrigation does not eliminate soil salt from fields and so its long-term use would enlarge the salinization area [5-8]. Some research [11] has reported that secondary salinization is caused when the water table is high, and moreover, the rate of evaporation 
is higher than rainfall, and then soil salt increases on the surface. In the process of secondary salinization, the soil deteriorates with the annual accumulation of soil salt. However, the numerical simulation and observations of soil salt under mulched drip-irrigation from this research reported that the static distribution and dynamic migration of salt content under mulching differed from that of secondary salinization.

\subsection{Increase in Surface Salinity on Bare Land Outside Mulch Is Due to the Salt Redistribution}

Field observations showed a change in soil salt distribution on bare land outside mulch and surface salinity at a depth of $20 \mathrm{~cm}$ was high even in the early stages after drip irrigation and mulching. However, soil salinity was low at the depth higher than $20 \mathrm{~cm}$. The simulation results showed that under drip irrigation, the increase in surface salinity on the bare land outside mulch was due to the horizontal transport of salt from the under-mulch to the bare land outside. Under the intense surface evaporation, the salt gathered at the surface, but soil salt content in the layer below the surface was declining. This process of salt accumulation due to redistribution differed from the secondary salinization. The following results indicated that the process of surface salt accumulation by salt redistribution is different from secondary salinization: First, the surface salinity on bare land is actually the salts transported to soil outside the mulch from under the mulch; and second, this transportation of salinity was not caused by the upward movement of groundwater, but mainly by surface evaporation. Therefore, the increase in surface salinity under fresh-water irrigation was not secondary salinization, but the surface accumulation of soil salt.

Farmland should be deeply plowed at the start of winter or early spring to mix the soil under and outside the mulch and to horizontally exchange soil salt (especially salt on the surface). However, once drip irrigation is started, a new desalted zone under mulch and a salt accumulation zone outside the mulch will be formed again. It is likely that the newly-formed salt accumulation zone outside the mulch would not coincide with the previous salt accumulation zone, thus the possibility of year-by-year salt accumulation on bare land outside the mulch would be reduced. The distribution of soil salinity in field 1, which had been under drip irrigation for 13 years, indicated that the salt content of the surface on bare land outside the mulch $\left(2.08-5.267 \mathrm{~g} \mathrm{~kg}^{-1}\right)$ in 2010 was lower than the initial salt contents $\left(29.5 \mathrm{~g} \mathrm{~kg}^{-1}\right)$. This result showed that the salt content of the surface on bare land outside mulch was not accumulating, but reducing year-by-year. Soil salt under mulch can reduce with extended use of drip irrigation and tend toward stability [2]. Accordingly, the phenomenon of surface salt accumulation on bare land outside mulch would not accumulate year after year and is basically different from secondary salinization.

\subsection{Aggregation of Surface Salinity Only Occurs in Small Bare Land Area}

Observation showed that surface salt content on the bare land outside mulch under drip irrigation was higher than that in the layer below, and there was a change in salt content at a depth of $20 \mathrm{~cm}$; in addition, in the same year under drip irrigation, the surface salt content on bare land outside mulch was also basically higher than that of under-mulch. However, the respective widths of bare and mulched areas showed that the bare area only represented $14 \%$ of the farmland area and the remaining area was under mulching, so increases in surface salinity only appeared in a small area and could not deteriorate into secondary salinization. The results of field observations and the numerical simulation showed that salt content in the below-surface layer was reduced with continuous use of drip irrigation. Surveys by other researchers also illustrate that salt only accumulated on the bare land outside mulch with drip irrigation under film in southern Xinjiang [23,24].

All of these further indicate that aggregation of surface salinity differs from secondary salinization as the latter will gradually cause deterioration of the soil condition while the former will not [2]. 


\subsection{Secondary Salinization under Drip Irrigation}

Some scholars have reported the phenomenon of secondary salinization when brackish water was used for drip irrigation. In research on brackish water, drip-irrigation salt accumulated extensively on the bare area outside mulch at the seedling stage of cotton within depths of $0-40 \mathrm{~cm}$ with little changes in salt under the mulch; however, at the later growth stage of cotton, soil salinity increased within depths of $0-60 \mathrm{~cm}[25,26]$. The salt accumulation was more in fields with continuous brackish water drip-irrigation in an arid area and if required measures were not taken to wash salt, soil salinity would eventually accumulate to levels harmful to crop growth [5,27]. Zhang [6] observed secondary salinization using $2.52 \mathrm{~g} \mathrm{~L}^{-1}$ brackish water for drip irrigation and concluded that the main causes of secondary salinization were that drip irrigation without drainage caused a rise in groundwater, which leads to soil salt accumulation; and second, less and shallow plowing was ineffective for mixing soil, resulting in salt build up on the surface, and further reason was the overuse of fertilizer. Sulitan [28] carried out a trial of drip irrigation under mulch by using different dripper discharge rates, irrigation water had $\mathrm{pH} 8.39$, and salt levels of $0.310 \mathrm{~g} \mathrm{~L}^{-1}$. After consecutive farming for three years, the soil salt content within the depths of $0-100 \mathrm{~cm}$ was $16 \%$ lower when the dripper flow was $2.6 \mathrm{~L} \mathrm{~h}^{-1}$. When dripper flow was $3.2 \mathrm{~L} \mathrm{~h}^{-1}$, salt accumulated on the surface, and it was considered that under this condition, the irrigation rate was faster than the infiltration rate and salt was not leached to deeper levels. Instead, salt was driven to both sides of the drip irrigation zone and salt accumulation on the surface outside the mulch.

Our observations showed that underground drainage of field 2 was good, and depth to underground water was $\geq 3 \mathrm{~m}$. Depth to underground water in field 1 rose to $0.8 \mathrm{~m}$ on 22 April after the field was irrigated twice consecutively from 16-20 April 2009; however, a week later, it returned to $2.8 \mathrm{~m}$. Therefore, the salt accumulation observed in these fields was not due to the rise in underground water and could not be defined as secondary salinization. In addition, additional irrigation was supplied in the middle of September for salt leaching, which further reduced the accumulation of salt year by year.

\section{Conclusions}

Two years of field observations and numerical simulation analysis indicated that drip irrigation with fresh water under mulching did not cause secondary salinization when the depth of groundwater was more than $3 \mathrm{~m}$. The salt accumulation appeared in the bare area outside the mulch at a depth of $0-20 \mathrm{~cm}$ of soil, which showed sudden changes in salt content. The soil layer below a depth of $20 \mathrm{~cm}$ in the bare area showed desalination. Salt content in the whole bare area outside mulch was distributed in a $\Gamma$-shape and decreased with increasing time of drip irrigation. Salt content of the bare surface outside the mulch after 13 years of drip irrigation was higher than that of deeper soil, but it was much lower (only 17\%) when compared to the previous level. This indicated that after drip irrigation, the soil salt under mulch moved to the deeper soil and to the side by water movement, which entered into the bare area outside the mulch and accumulated on the surface by evaporation. Thus, surface salt accumulation in the field under drip irrigation was not the result of secondary salinization, but the redistribution and accumulation of salt on the surface.

Author Contributions: Conceptualization and software, Y.W.; Formal analysis and data curation, X.Z.; Writing-original draft preparation, H.L.; Writing-review and editing, S.A.; Supervision and project administration, M.L. All authors have read and agreed to the published version of the manuscript.

Funding: This research received no external funding.

Conflicts of Interest: The authors declare no conflict of interest.

\section{References}

1. Wang, Z.; Jin, M.; Šimůnek, J.; Van Genuchten, M.T. Evaluation of mulched drip irrigation for cotton in arid Northwest China. Irrig. Sci. 2013, 32, 15-27. [CrossRef] 
2. Li, M.; Liu, H.; Zheng, X. Spatiotemporal variation for soil salinity of field land under long-term mulched drip irrigation. Trans. Chin. Soc. Agric. Eng. 2012, 28, 82-87.

3. Guan, Z.; Jia, Z.; Zhao, Z.; You, Q. Dynamics and Distribution of Soil Salinity under Long-Term Mulched Drip Irrigation in an Arid Area of Northwestern China. Water 2019, 11, 1225. [CrossRef]

4. Mmolawa, K.; Or, D. Water and Solute Dynamics Under a Drip-Irrigated Crop: Experiments and Analytical Model. Trans. ASAE 2000, 43, 1597-1608. [CrossRef]

5. Wang, H.; Wang, K.; Hou, Z.; Xin, L. Effects on cotton growth and salinity changes in different soil depth of drip irrigation in cotton field. Ecol. Environ. Sci. 2010, 19, 2381-2385, (In Chinese with English abstract).

6. Zhang, W.; Lu, X.; Li, L.; Liu, J.; Sun, Z.; Zhang, X.; Yang, Y. Salt transfer law for cotton field with drip irrigation under the plastic mulch in Xinjiang Region. Trans. CSAE 2008, 24, 15-19, (In Chinese with English abstract).

7. Yang, H.; Chen, Y.; Zhang, F. Evaluation of comprehensive improvement for mild and moderate soil salinization in arid zone. PLOS ONE 2019, 14, e0224790. [CrossRef] [PubMed]

8. Wang, Z.; Fan, B.; Guo, L. Soil salinization after long-term mulched drip irrigation poses a potential risk to agricultural sustainability. Eur. J. Soil Sci. 2018, 70, 20-24. [CrossRef]

9. Sakadevan, K.; Nguyen, M.-L. Extent, Impact, and Response to Soil and Water Salinity in Arid and Semiarid Regions. In Advances in Agronomy; Elsevier BV: Amsterdam, The Netherlands, 2010; Volume 109, pp. 55-74.

10. Wang, F.; Chen, X.; Luo, G.; Han, Q. Mapping of regional soil salinities in Xinjiang and strategies for amelioration and management. Chin. Geogr. Sci. 2014, 25, 321-336. [CrossRef]

11. Wang, S.L.; Zhou, H.P.; Qu, X.Y.; Guan, X.Y. Study on directional salt transport and surface salt draining under mulched drip irrigation in arid areas. J. Hydr. Eng. 2013, 44, 549-555.

12. Tian, F.; Ni, G.; Hu, H. Experimental study on soil water-salt movement and irrigation scheduling for cotton under mulched drip irrigation condition. J. Hydr. Eng. 2010, 12, 1483-1490, (In Chinese with English abstract).

13. Hassan, G.; Persaud, N.; Reneau, R.B. Utility of Hydrus-2d in Modeling Profile Soil Moisture and Salinity Dynamics Under Saline Water Irrigation of Soybean. Soil Sci. 2005, 170, 28-37. [CrossRef]

14. Lei, Z.; Yang, S.; Xie, S. Soil Water Dynamics; Tsinghua University Press: Beijing, China, 1988; pp. 77-80.

15. Li, Y.; Pang, H.; Zhang, H.; Chen, F.L. Effect of irrigation management on soil salinization in Manas River Valley, Xinjiang, China. Front. Agric. China 2008, 2, 216-223. [CrossRef]

16. Zhang, Q.; Li, G.; Chai, F. Effect of mulched drip irrigation frequency on soil salt regime and cotton growth. J. Hydr. Eng. 2004, 9, 123-126, (In Chinese with English abstract).

17. Tan, J.; Kang, Y.; Jiao, Y.; Liu, W.; Dong, F. Effects of cropping years on soil salinity and pH value in fields under drip irrigation condition. Trans. CSAE 2009, 25, 43-47, (In Chinese with English abstract).

18. Sun, J.; Kang, Y.; Wan, S.; Hu, W.; Jiang, S.; Zhang, T. Soil salinity management with drip irrigation and its effects on soil hydraulic properties in north China coastal saline soils. Agric. Water Manag. 2012, 115, 10-19. [CrossRef]

19. Wang, R.; Kang, Y.; Wan, S.; Hu, W.; Liu, S.; Jiang, S.; Liu, S. Influence of different amounts of irrigation water on salt leaching and cotton growth under drip irrigation in an arid and saline area. Agric. Water Manag. 2012, 110, 109-117. [CrossRef]

20. Wang, Y.Q.; Liu, H.G.; Zhu, Y.J. Salinity Migration Rule under Mulching Plastic Drip Irrigation in Heavy Salty Soil. J. Irr. Drainag. 2010, 29, 58-60.

21. Richards, L.A. Capillary Conduction of Liquids Through Porous Mediums. Physics 1931, 1, $318-333$. [CrossRef]

22. Van Genuchten, M.T. A Closed-form Equation for Predicting the Hydraulic Conductivity of Unsaturated Soils. Soil Sci. Soc. Am. J. 1980, 44, 892-898. [CrossRef]

23. Liu, M.; Yang, J.-S.; Li, X.; Liu, G.; Yu, M.; Wang, J. Distribution and dynamics of soil water and salt under different drip irrigation regimes in northwest China. Irrig. Sci. 2012, 31, 675-688. [CrossRef]

24. Wang, R.; Kang, Y.; Wan, S.; Hu, W.; Liu, S. Effect of Soil Matric Potential on Poplar Growth and Distribution of Soil Salt under Drip Irrigation in Saline-sodic Soil in Arid Regions. J. Irrig. Drain. 2013, 31, 1-6.

25. Mai, W.; Tian, C.; Li, C. Soil Salinity Dynamics under Drip Irrigation and Mulch Film and Their Effects on Cotton Root Length. Commun. Soil Sci. Plant Anal. 2013, 44, 1489-1502. [CrossRef]

26. Liu, X.; Tian, C. Study on Dynamic and Balance of Salt for Cotton under Plastic Mulch in South Xinjiang. J. Soil Water Conserv. 2005, 19, 82-84, (In Chinese with English abstract). 
27. Hou, Z.; Wang, Y.; Gong, J.; Xiao, L.; Ma, L.; Qi, T. Salt Distribution and Accumulation as Affected by Underfilm Drip Irrigation with Saline Water in an Arid Region. Chin. J. Soil Sci. 2008, 1, 16-24, (In Chinese with English abstract).

28. Danierhan, S.; Shalamu, A.; Tumaerbai, H.; Guan, D. Effects of emitter discharge rates on soil salinity distribution and cotton (Gossypium hirsutum L.) yield under drip irrigation with plastic mulch in an arid region of Northwest China. J. Arid. Land 2012, 5, 51-59. [CrossRef]

Publisher's Note: MDPI stays neutral with regard to jurisdictional claims in published maps and institutional affiliations.

(C) 2020 by the authors. Licensee MDPI, Basel, Switzerland. This article is an open access article distributed under the terms and conditions of the Creative Commons Attribution (CC BY) license (http://creativecommons.org/licenses/by/4.0/). 